\title{
Special Issue Introduction The Role of Conceptual and Theoretical Scholarship in Understanding Research in Digital Learning
}

\author{
Richard E. West \\ Brigham Young University. Brigham, USA
}

The goal of research is to understand our world and the people in it. This understanding comes through a variety of methods and strategies that each uncover a different layer of knowledge that can contribute to this overall understanding. As researchers, we are much like a young child seeking to understand their surroundings by first touching a new toy, then lifting it, then shaking it, then even tasting it! Each of these strategies tells the child a little more about the object.

Similarly, as we seek to understand and influence our world, we need the knowledge gained from a wide variety of scholarly methods. In the following table, I describe several of the common methods for developing knowledge within a domain. Each of these methods contributes a different kind of insight or way of knowing unique to that method, but equally essential in understanding the whole. An effective scholar recognizes that to truly understand the corner of the universe they study, they must embrace all of these different ways of knowing more about their topic.

Table 1. A summary of various forms of academic scholarship, their characteristics, and their contributions to understanding within a discipline.

\begin{tabular}{|l|l|l|}
\hline Type of Scholarship & Characteristics & Contributions \\
\hline $\begin{array}{l}\text { Literature } \\
\text { Review/meta-analysis }\end{array}$ & $\begin{array}{l}\text { Rigorously retrieves relevant } \\
\text { articles according to inclusion } \\
\text { criteria, and synthesizes findings } \\
\text { either through inductive/deductive } \\
\text { categorization or statistical } \\
\text { procedures. Quality is determined } \\
\text { by the rigor of the search, retrieval, } \\
\text { inclusion/exclusion criteria and } \\
\text { analysis methods. }\end{array}$ & $\begin{array}{l}\text { Identifies what is known about } \\
\text { a topic, and what needs to be } \\
\text { better understood through } \\
\text { future research, design, or } \\
\text { theory. Contextualizes and } \\
\text { synthesizes research within a } \\
\text { scholarly community of } \\
\text { discourse. }\end{array}$ \\
\hline Conceptual & $\begin{array}{l}\text { Based on an in-depth reading of } \\
\text { existing research literature, } \\
\text { identifies key concepts that } \\
\text { characterize a phenomenon and } \\
\text { how they are related to each other. } \\
\text { Quality is determined by the } \\
\text { accurate identification of all } \\
\text { relevant concepts on the topic, and } \\
\text { useful organization into a } \\
\text { framework that promotes future } \\
\text { action. }\end{array}$ & $\begin{array}{l}\text { Clarifies concepts unique to a } \\
\text { phenomenon, leading to rich } \\
\text { recommendations for future } \\
\text { research, design, or practice. } \\
\text { Can lead to the development of } \\
\text { new theory, particularly by } \\
\text { identifying missing pieces in } \\
\text { conceptual frameworks. When } \\
\text { represented visually, is often } \\
\text { referred to as a model. }\end{array}$ \\
\hline
\end{tabular}

RED. Revista de Educación a Distancia. Núm. 64, Vol. 20. Artíc. 0, 30-09-2020

DOI: https://doi.org/10.6018/red.444211 


\begin{tabular}{|c|c|c|}
\hline Theoretical & $\begin{array}{l}\text { Critiques the boundaries of existing } \\
\text { theories and/or argues for new } \\
\text { theory that can potentially explain } \\
\text { a phenomenon and should be } \\
\text { verified or explored through } \\
\text { research. Quality is determined by } \\
\text { the strength of the argument and } \\
\text { evidence presented, the relevance } \\
\text { of the contextualizing literature, } \\
\text { and the usefulness of the theory to } \\
\text { developing future research and } \\
\text { design/practice. }\end{array}$ & $\begin{array}{l}\text { Good theory suggests new } \\
\text { variables, connections, or } \\
\text { applications of a phenomenon } \\
\text { that can be verified empirically. } \\
\text { It can guide design and } \\
\text { practice, particularly by } \\
\text { revealing otherwise unknown } \\
\text { aspects of a phenomenon. In } \\
\text { emerging fields such as } \\
\text { digital/online learning, strong } \\
\text { theory guides practice until } \\
\text { research can provide } \\
\text { verification. }\end{array}$ \\
\hline Exploratory Research & $\begin{array}{l}\text { Typically describes subjects in } \\
\text { their natural, uncontrolled } \\
\text { environments. Further develops } \\
\text { theory by exploring the suggested } \\
\text { variables and constructs through } \\
\text { descriptive empirical investigation. }\end{array}$ & $\begin{array}{l}\text { Develops the potential } \\
\text { boundaries and limitations of a } \\
\text { theory or conceptual model. } \\
\text { Can contribute understanding } \\
\text { of the human side of a topic, } \\
\text { developing empathy and rich } \\
\text { understanding for how humans } \\
\text { experience the phenomenon. }\end{array}$ \\
\hline Explanatory Research & $\begin{array}{l}\text { Verifies and validates theory } \\
\text { through testing and defining of the } \\
\text { involved variables. Utilizes various } \\
\text { statistical procedures to objectively } \\
\text { study and test the veracity of } \\
\text { theoretical claims. }\end{array}$ & $\begin{array}{l}\text { Provides the strongest } \\
\text { predictive claims, leading to } \\
\text { greater confidence in } \\
\text { establishing causal } \\
\text { connections. }\end{array}$ \\
\hline Critical Analysis & $\begin{array}{l}\text { Provides rich understanding of the } \\
\text { effects of a phenomenon on } \\
\text { people, particularly minoritized } \\
\text { people. Explores the meaning of } \\
\text { personal experience with a } \\
\text { phenomenon as well as advocates } \\
\text { for societal actions and progress. }\end{array}$ & $\begin{array}{l}\text { Mobilizes research and theory } \\
\text { into actionable policies and } \\
\text { activities to improve human } \\
\text { experiences through } \\
\text { reorganizing societal structures } \\
\text { and norms. }\end{array}$ \\
\hline $\begin{array}{l}\text { Design-based } \\
\text { Research (DBR) }\end{array}$ & $\begin{array}{l}\text { DBR uniquely seeks to develop } \\
\text { both local/generalizable theory as } \\
\text { well as mature design } \\
\text { interventions. Thus, DBR research } \\
\text { will be both a design case as well } \\
\text { as research study, usually } \\
\text { presented as a series of iterations } \\
\text { of both the theory and the } \\
\text { design/intervention. }\end{array}$ & $\begin{array}{l}\text { Privileges the intimate } \\
\text { knowledge that a } \\
\text { designer/creator gains about } \\
\text { an intervention through the } \\
\text { process of creating it. While } \\
\text { contributing to generalizable } \\
\text { theory, DBR equally } \\
\text { contributes insight and design } \\
\text { knowledge useful for acting in } \\
\text { local contexts. }\end{array}$ \\
\hline
\end{tabular}

The Role of Conceptual and Theoretical Scholarship in Understanding Research in Digital Learning. Richard E. West. 
Boote and Beile (2005) famously stated that we needed to be "scholars before researchers." They effectively argued for the legitimacy and critical need for literature review syntheses as a foundation for effective research. I propose extending their argument, that in order to effectively conduct research, we must become skilled not only at conducting literature review syntheses, but also in doing the hard conceptual and theoretical work that provides a bedrock of context and understanding for high quality exploratory/explanatory/design research.

Unfortunately, many researchers and publishers neglect or even disparage the need to embrace all these various ways of gaining knowledge on our research topics. Instead, we find "paradigm wars" as scholars divide into tribes representing various ways of conducting scholarship, and they arrogantly argue for the supremacy of their individual approaches. In my career, I have found journals (or individual reviewers) that stubbornly refuse to consider any paper not utilizing their preferred approach to scholarship.

Part of the reason for this bias against certain types of scholarship derives from pressures within the academic system. Many universities, for example, may only accept a certain type of scholarship as consideration for promotion and tenure. Even some governments may strive to limit scholarship to only one approach that is considered "evidence-based." In other cases, journals may follow the leadership of their editorial board in eschewing some approaches towards scholarship in favor of more approved methods.

We need to reconsider these limiting approaches to scholarship, and instead embrace a variety of methods for knowing and understanding our topics. If we are to truly understand the complexity of how to help people learn, especially in the shifting sands of digital learning, we need to be both scholars and researchers, both theorists and designers. We must develop the abilities to see the learning process through multiple frames, or at least to lean upon the work of other scholars whose strengths can compensate for our weaknesses.

In addition, we must work to change our academic systems to give credit to and acknowledge the contributions of all legitimate forms of scholarships. This includes reconsidering promotion and tenure guidelines to recognize rigorous design work as a type of scholarship that informs and impacts the discipline. It also includes encouraging journal editorial boards and reviewers to recognize literature reviews and conceptual/theoretical contributions as equal to their empirical cousins, and to revise official journal policy statements to reflect this openness. As new reviewers join our ranks, there must be training on the norms for recognizing quality and rigor in all of these scholarly approaches. As I have written elsewhere, "solid theoretical foundations about learning, teaching, design, and technology separate instructional designers from website developers, teachers from presenters, and academics from commentators" (West, et al., 2020, p. 593). Without utilizing all these various forms of scholarship, the power and usefulness of our academic work is severely limited.

This special issue is one small step in this direction, by collecting articles that discuss theoretical and conceptual approaches to their topics. Each of these papers is quite different, but as a whole 
they continue the discussion about the importance of both empirical as well as non-empirical approaches to scholarship about digital and online learning. Reigeluth and Honebein begin the issue articulating six principles of their instructional theory framework that can guide design and research. Anderson and West then report findings from a synthesis of the literature on mentoring, applying their findings to online mentoring needs. Stefaniak and $\mathrm{Xu}$ then describe a conceptual framework to guide instructional design decisions for authentic learning experiences in digital environments. Michael Barbour provides a helpful review of the history of the virtual schooling movement, and argues for compelling needs for the field, both in future research and practice. Polly and Byker, in their paper, apply Vygotsky's sociocultural learning to teacher preservice training, and Blaschke and Marín describe heutagogy theory and how e-portfolios can be a useful tool for applying this theory to the development of students. Ivanov, Kosonogova, and Cabo also look to social constructivist theories from Vygotsky, this time applying them to digital learning environments. Finally, Cardenas, West, Swan, and Plummer describe the theoretical foundation for decision-based learning, a new pedagogy for teaching conditional knowledge.

While these articles are all very different in the theories and concepts they address, together they present models for how review, conceptual, and theoretical contributions can strengthen and guide empirical research in the domain of digital and online learning.

Presentación del manuscrito: 16 de enero de 2020

Fecha de aprobación: 16 de enero de 2020

Fecha de publicación: 30 de septiembre de 2020

West, R.E. (2020). The Role of Conceptual and Theoretical Scholarship in Understanding Research in Digital Learning. . RED. Revista Educación a Distancia, 20(64). https://doi.org/10.6018/red.444211

\section{Funding}

This research has not received any specific grant from funding agencies in the public, commercial or non-profit sectors.

\section{References}

Boote, D. N., \& Beile, P. (2005). Scholars before researchers: On the centrality of the dissertation literature review in research preparation. Educational researcher, 34(6), 3-15.

West, R. E., Ertmer, P., \& McKenney, S. (2020). The crucial role of theoretical scholarship for learning design and technology. Educational Technology, Research and Development, 68(2), 593-600. 